\title{
A Critical look at Educational Technology from a Distance Education Perspective
}

\author{
Terry Anderson \\ terrya@athabascau.ca \\ Athabasca University, Canada \\ Pablo Rivera-Vargas \\ pablorivera@ub.edu \\ Universitat de Barcelona, España \\ Universidad Andrés Bello, Chile
}

\begin{abstract}
This article focuses on educational technology as applied in the context of programs and institutions that offer completely distance education courses. All education in the 21st century is digital education in that the use of networking, text and image creation and editing and search and retrieval of information punctuates the life of almost every teacher and student. However, the context of distance education where all the interactions are mediated, creates a unique and heightened context of digitalization. This paper focuses on two questions: (1) What aspects have not been completely satisfactory in the transit and transformation that education has undergone, from its more traditional, campus-based conception, towards its new configuration marked by the continuous use of digital technologies and environments? (2) What are the future challenges that distance education must deal with to support sustainability of this teaching model?

From a theoretical and interpretative analysis, based on the review of relevant articles and documents on distance education, some critical dimensions (limitations, shortcomings and future challenges) the use of digital technologies in distance education is identified and subsequently analyzed. These dimensions evidence how the initial (sometimes excessive) promises of digital technologies in distance education has not (yet) been fully reflected in reality.
\end{abstract}

\section{Keywords}

Distance education; online education; learning analytics; educational technology; threaded discussion 


\section{Introduction}

The great changes that the society has experienced in recent times, from its original traditional configuration, to the current postmodern dynamic, have transformed all forms of education in multiple ways - and higher education is not an exception.

During much of the twentieth and early twenty-first centuries, we have been able to recognize two macro models of university education: face-to-face, or campus-based education and distance education. The extensive literature from this field of study allows us to recognize the main characteristics, objectives and practices of both models of education (Bates, 2005; Fallon \& Brown, 2016).

When we talk about face-to-face education, we refer to the traditional teaching model that takes place in a physical classroom. This physical proximity between teacher and student can favor interaction and communication between and among students and teacher. However, it has also been associated with restrictions of both geographic and temporal access. Digital tools have been gradually incorporated into the teaching experience, although they tend to be used basically as didactic support (Gaebel, Kupriyanova, Morais, et al., 2014) to in person communications and access to content.

Distance education, is a teaching model that is usually asynchronous and always distributed. That is, there is no need to attend classes in a specific physical environment and usually not at a particular time. The student receives and accesses the content to engage with their studies, then completes and transmits evaluation and often collaborative activities, and can ask their teacher questions through mediated means: initially by traditional mail, telephone, fax, and during the last decades, through various online tools (Alfonso, 2003; Sangrà, Vlachopoulus \& Cabrera, 2012).

Literature has allowed us to identify four contexts of distance education (Bates, 2005; García, 2009; Sangrà, Vlachopoulus \& Cabrera, 2012):

1. Distance education without virtual environments: This is the original form of distance education and that, given the increasing extent of internet access by the population, is decreasing in importance (with the exception of those areas of very low economic development and low population access to telematics networks including prisons).

2. Distance education with complementary virtual environments: This modality emerged in distance education institutions that developed a conventional model and at the beginning of the nineties, began to introduce the use of the telecommunications in their programs. Initially this was supported by audio, but later video, immersion and other modes of internet based technology were used. This environment is also decreasing (with the exception of those areas of low economic development and poor population access to telematics networks).

3. Teaching in dual or bimodal environments: These are mixed or combined teaching, also referred to as blended learning, distributed learning, etc. This model is the result of the symmetric coexistence of the two classic models; face-to-face and remote, in the same institution.

4. Teaching in virtual environments (e-Learning): This term is used to describe distance learning that essentially uses the tools provided by the internet (through virtual environments) as a means of transmission of knowledge, communications amongst and between students and teacher and the management of the education process. 
Much of the literature raises a distinction between what distance education and e-Learning represent - placing the former in its most traditional (and static) definition and the latter as a direct consequence of the massification of digital technologies, and not necessarily as an evolution of distance education (Guri-Rosenblit \& Gros, 2011; Sangrà, Vlachopoulus \& Cabrera, 2012). At the same time, there is also considerable amounts of literature that tends to use the two terms interchangeably (Arafeh, 2004; Annand, 2007; Harasim, 2000; Huang, Lin \& Huang, 2012; Kocdar, Karadeniz, Bozkurt \& Buyuk, 2018). In essence, distance education dates back to the end of the 19th century. Since that time, like campus education, it has evolved in line with social and technological transformations that the world has undergone. In its digital and online version, it does not necessarily represent a break or an entirely new model, but rather an evolution of the model, which is afforded by the development of the internet and the widespread use of digital technologies. This understanding of distance education is what the authors share and assume for the development of this article.

Distance education, in its traditional definition, can be understood as the physical separation of the student and the instructor, at least in certain stages of the learning process. However, in the present, distance would not be a defining characteristic of this modality. Although it is challenging to replace completely the physical separation of the student with the teacher (in the teaching/learning process) through the use of digital technologies, it might be possible to build a collaborative, virtual pedagogical space which does not reproduce distance between the different actors of educational process and between these and the content (GuriRosenblit \& Gros, 2011). The dream is that this utopian learning environment reality can be created, now or in the near future, using the tools and means available in the digital society in which we are situated.

In this article, we are looking at both the promise and the reality of educational technologies developed for application in distance and distributed educational contexts. On the one hand, within the subset of formal education that we refer to as distance education (including most current forms of online or e-learning), questioning the value of technology use is ridiculous. Without educational technology, there is no distance education. On the other hand, the explosion of applications using a variety of educational technologies to support distance education, gives rise to concerns and need for study of both the cost and the consequence of use of different types, applications and contexts of educational technology used in distance education.

Without doubting the successes and increase in numbers of participants engaged in distance education programming ${ }^{1}$, in this article we ask ourselves the opposite, that is, what are the costs and promises left pending fulfillment: (1) What aspects have not been completely satisfactory in the transit and transformation that Distance Education has undergone since the inclusion of the active use of digital technologies and environments? (2) In order to sustain this teaching/learning model, what are the future challenges that distance education will face?

To answer these questions, we have carried out a theoretical and interpretative analysis, based on the review of relevant articles and documents on Distance Education ${ }^{2}$, and from our personal knowledge based on experiences of the authors in this field of study ${ }^{3}$. As a

\footnotetext{
1 That has been presented in different environments of manifest legitimacy and academic quality. (Gossenheimer, Bem, Carneiro, \& de Castro, 2017; Russell, 1999; Shachar, 2010; Sangrà, Vlachopoulus \& Cabrera, 2011; and others...)

2 Documents and articles whose emphasis was placed on the description of technological innovations applied to distance education, results of relevant research and critical theoretical reviews.

3 Particularly of the professor Terry Anderson, who with more than 40 years of research and teaching experience in Distance Education, is one of the most respected voices internationally in the field.
} 
result of this exercise, critical elements regarding the use of digital technology in Distance Education have been identified and subsequently analyzed. These elements have been grouped into two relevant dimensions:

(1) Historical and conceptual approach to Distance Education. From its origins and evolution, to the transformation it has experienced before the arrival of the information society and the consequent digital society.

(2) Critical elements in the use of digital technologies in Distance Education. We have subdivided this dimension into two parts. (a) Until now: broken promises and unmet goals, composed of five categories. (b) Current and future challenges (and risks), composed of three categories.

The following table shows the result of the work carried out, and the generation of dimensions and categories of analysis.

\begin{tabular}{|c|c|c|}
\hline Dimension & sub dimension & category \\
\hline \multirow{2}{*}{$\begin{array}{l}\text { Definitions and a Historical } \\
\text { Description of Distance } \\
\text { Education and Educational } \\
\text { Technology }\end{array}$} & $\begin{array}{l}\text { Evolution of distance } \\
\text { education based upon the } \\
\text { technology employed }\end{array}$ & \\
\hline & $\begin{array}{l}\text { Educación a distancia en la } \\
\text { sociedad digital }\end{array}$ & \\
\hline \multirow{8}{*}{$\begin{array}{l}\text { An approach to the main } \\
\text { critical perspectives on } \\
\text { Educational Technology } \\
\text { from a Distance Education } \\
\text { perspective }\end{array}$} & \multirow{5}{*}{$\begin{array}{l}\text { Until now: broken promise and } \\
\text { unmet goals }\end{array}$} & Attrition rates \\
\hline & & Student-content interaction \\
\hline & & $\begin{array}{l}\text { Threaded discussion in distance } \\
\text { Education }\end{array}$ \\
\hline & & Copyright confusion \\
\hline & & $\begin{array}{l}\text { Utopian, compulsive and excessively } \\
\text { optimistic visions }\end{array}$ \\
\hline & \multirow{3}{*}{$\begin{array}{l}\text { Current and future challenges } \\
\text { (and risks) }\end{array}$} & $\begin{array}{l}\text { The Promise and Peril of Learning, } \\
\text { analytics in distance education }\end{array}$ \\
\hline & & Social Media in distance education \\
\hline & & Assimilation or singularity \\
\hline
\end{tabular}

Table 1. Dimensions and categories of analysis

Source: The authors

Finally, we would like to mention that the claim of this article is not in any case to close the analytical focus of the problem. Nor to entertain deterministic and causal answers. Rather, it is proposed to present relevant elements for the analysis of the current configuration of Distance Education, in order to enhance its inclusive and innovative role in our education systems. 


\section{Definitions and a historical description of distance education and educational technology}

Distance education is commonly defined as formal education (accredited by an educational institution) in which the students and the teacher are separated in time and/or distance. The experience may occasionally include face-to-face tutorial sessions or face-to-face gatherings for the purposes of support, remediation or examination. However, the majority of the educational experience is mediated by some form of technology.

\section{a. Evolution of distance education based upon the technology employed}

Distance education theorists have often defined four generations of distance education based upon the technology employed (Garrison, 1985; Keegan, 1993; Taylor, 1995).

The first generation of distance education is often traced back to Putman's shorthand newspaper and correspondence courses of the 1850s. This first, print based generation using post or email correspondence continues in wide use in developing countries today (Taylor, 1995). This 1st generation relied upon the educational technology of printed books or newspapers (to support student-content interaction) and the slow technology of postal service to provide student - teacher interaction. There was effectively no student-student interaction. Education was perceived as a knowledge transmission process whereby expertly produced content was shipped and students were expected to learn, remember and then demonstrate their new knowledge through standardized, summative examinations.

The second generation evolved to a one-sided teacher-student interaction that merged with student-content interaction in the form of radio, television and later web streaming technologies. Initially, in 1922, The Pennsylvania State College and The University of Columbia began their training courses via radio. The State University of Iowa did the same in 1925, an institution that in 1934, became the first to begin teaching using filmed courses. However, the great progress and expansion of this second generation of distance education is achieved with the end of World War II, the result of the destruction and closure of multiple educational centers, technological development and the consequent need to facilitate access to educational centers at all levels, especially in the countries involved in the war (Alfonso, 2003). The correspondence education system was replaced in some countries by the oneway education system, which began to be demonstrated massively in the 1950s and was in popular use in the 1970s through the use of electronic media, such as audio tapes, videotapes, radio, television and computers (Rivera-Vargas, Alonso y Sancho, 2017). In this context, in the early 1950s, the Ford Foundation began to develop and deliver educational programs on television. Subsequently, in 1968, Stanford University created a university training network developed through a television channel.

The third generation of distance education saw the introduction of interactive courses first via teleconferencing and later using online technologies. These were initially supported asynchronously via computer conferencing and later through synchronous interactions and the evolution of learning management systems. This, third generation saw the first emergence of the capacity for learner-learner interaction, thus allowing distance education to move from a predominantly one-way interaction based on behaviorist and cognitive learning theories to ones based upon constructivism with the capacity for collaborative and cooperative learning activities (Anderson \& Dron, 2012). 
The emergence of intelligent agents, the semantic web, learning analytics and other online technologies has opened the door for 4th generation distance education that not only support student-teacher, student-student and student-content interactions but adds the support for content to interact with other content, for teachers to interact with other teachers, and with 'smart content' as well (Anderson, 2003). From these enhanced interaction possibilities, a new generation of distance education pedagogy based upon connectivism has arisen (Wang, Anderson, Chen, \& Barbera, 2017). The technological affordances of ubiquitous networks were overviewed when Jon Dron and Anderson (2014) provided examples in which distance education has evolved from interaction between individual students and their teachers to group, network and set based interactions using a variety of online technologies.

The history and evolution of distance education may (and often is) criticized as being driven by technological determinism (Kirkwood, 2014). Indeed, there are some distance educators and theorists who feel a compulsion to pilot and assess every new technology that appears on the market. Moreover, each generation of both technology and pedagogy of distance education has required ever more sophisticated technologies. We often point out that the most common model of distance education in terms of student numbers is still, by far, 1st generation based upon printed texts and post or email interactions. Despite some efforts to move to more sophisticated technologies the so called mega universities (those having more than 100,000 students) (Daniel, 2013) all use 1st or 2nd generation distance education technologies. At the University of South Africa $^{4}$, for example, with over 400,000 students, it is possible to observe how the universities copes with courses enrolling upwards of 10,000 students per semester, demonstrating that even older education technologies may be the most appropriate when delivering education at this scale.

\section{b. Distance education in the digital society}

The increasingly frequent use of digital technologies in education has allowed greater access to the university through more flexible models (Garrison \& Anderson, 2005). An example of this is the proliferation and diversification in recent times of non-contact training modalities: e-learning, MOOCS, streaming video, flexible certification mechanisms, among others. This increase occurs within the context of new demands of employability including the demand for students to train and assimilate new skills throughout their lives. In Spain, for example, according to data from the Ministry of Education (2018) the enrollment in distance universities has increased exponentially in the last twenty years. This has been accompanied by the increase in the percentage of students enrolled in non-contact universities with respect to the total number of students enrolled in Spanish universities. For example, as can be seen in table 2, while in the 1987-1988 academic year, those enrolled in non-contact universities represented only $4 \%$ of the total, for the 2017-2018 academic year it already reaches $16 \%$. In many developing countries, this percentage of distance students is even higher - and growing.

\begin{tabular}{|c|l|l|l|c|}
\hline & $\begin{array}{l}\text { Face to } \\
\text { face } \\
\text { education }\end{array}$ & $\begin{array}{l}\text { Distance } \\
\text { education }\end{array}$ & $\begin{array}{l}\text { Total number of } \\
\text { enrolled in } \\
\text { Spanish Ues }\end{array}$ & $\begin{array}{l}\text { \% Enrollment distance } \\
\text { education Universities } \\
\text { in relation to the total } \\
\text { enrollment }\end{array}$ \\
\hline Total & Total & & Total \\
\hline
\end{tabular}

\footnotetext{
${ }^{4}$ Professor Terry Anderson recently visited this university, and observed this reality in his own context.
} 


\begin{tabular}{|r|c|c|c|c|c|}
\hline $2017-2018$ & 1.494 .231 & 16 \\
\hline Total & 1.258 .902 & 235.329 & 1.423 .171 & 13 \\
\hline Total & 1.237 .321 & 185.850 & 1.574 .484 & 9 \\
\hline 1997-1998 $007-2008$ & 1.435 .706 & 138.778 & 938.339 & 4 \\
\hline
\end{tabular}

Table 2 . Students enrolled in the last 30 years by type of university

Source: The authors based on data from the S.G. of Coordination and University Monitoring. Integrated University Information System (SIIU). Ministry of Education, Culture and Sports (2018).

In the case of the United States, according to Seaman, Allen \& Seaman (2018) the undergraduate enrollment of online students continues to grow (5.6\% between 2015 and 2016), in a context of total enrollment decline (-6.4\% from 2012 to 2016). This represents $31.6 \%$ of the total number of registered students, of which about half are enrolled in "exclusively online" programs, a segment that, according to the authors, is the fastest growing model in recent years.

Beyond the evident proliferation of distance education courses that are actively mediated by digital technologies, and the increase in non-face-to-face university enrollment, the incorporation of digital technologies in the campus university has also brought profound changes in design and analysis of the teaching-learning processes. Its possibilities and attributes, along with the increasing accessibility, has led some researchers to recognize the emergence of a new learning paradigm, Digital and Network Learning (Garrison \& Anderson, 2005; Castañeda \& Adell, 2013; Dolan, 2014; Kaplan \& Haenlein, 2016). This new paradigm emerges amid the current debate about the effectiveness and sustainability of educational models in the digital society. According to Sangrà, Vlachopoulus \& Cabrera (2011) the emergence of this new paradigm is understood from the interactions of the past, of the present, and with a view to the future:

These transformations that are taking place in the way of understanding modern teaching-learning processes, are explained from an evolution of the classic university models, overcoming in recent times, the distinction between face-to-face education and distance education (2011: 76).

The goals of this "new education" is to create an educational system capable of dealing with new learning and training demands presented in the digital society, accommodating new student profiles and giving legitimacy and visibility to formal and non-formal educational environments (Bates, 2005; Garrison \& Anderson, 2005; Sefton-Green \& Erstad, 2017; Cobo, 2017). However, the symptom of the "analogical inheritance" that affects higher education leads to questioning whether these more digital educational models are really disruptive cognitive and pedagogical transformations (Rivera-Vargas, Sancho-Gil \& Sánchez, 2017). Or they are simply a means of reducing costs, that is, reaching more students through an improvement in the mechanisms of distribution (delivery) of content (Dolan, 2014) but not necessarily any qualitative improvements in the ways of teaching and learning. 


\section{An approach to the main critical elements on the use of digital technologies in Distance Education}

As we have already mentioned in the introduction of this article we have subdivided this dimension into two parts. (a) Until now: broken promises and shortcomings, composed of five categories. (b) Current and future challenges (and risks), composed of three categories.

\section{a. Until now: broken promises and unmet goals}

Despite the use of educational technology in all types of distance education there have been many critical thinkers who have turned their analysis to the shortcomings and challenges of this mode of education. The most common critical approach (Noble,1998) is based, in large part, upon romantic idealizations of interaction between students and teachers in small, one to one or seminar classes. Distance educators have responded by noting the large distances - both geographic and social that often separate teachers from students in the large lecture theatres that are increasingly common on campus-based universities (Bates, 2005).

Few argue that distance education can provide the same experience as classroom-based education. In fact, the evidence from comparative samples shows that distance students most often achieve learning outcomes that are not significantly different (Gossenheimer, Bem, Carneiro, \& de Castro, 2017; Russell, 1999; Shachar, 2010) or positively skewed towards higher achievement of students enrolled in classroom-based education (Shachar \& Neumann, 2010).

However, without the intention of questioning the abundant evidence that demonstrates the achievements of distance education and the contributions that its own transformation and digitalization has generated in the world of education, it is clear that there are some limitations and outstanding challenges that it must address. We have identified five not entirely satisfactory elements that have been generated during the transition from traditional distance education to the current e-learning and online version.

Of course, these five elements do not represent taxative responses, much less rule out the existence of other critical elements. The selection has been made based on the distance education literature and the interests and experience of the authors of this article. Finally, they are presented only with the intention of contributing to the debate and academic discussion about the past and present of distance education.

\section{Attrition rates}

Distance education has legitimately been criticized for higher attrition rates and especially in those distance education systems that provide low levels of student support and those that use less interactive media and instructional designs (Shachar \& Neumann, 2010). Attrition is also higher in courses that attract younger students, those with multiple family or vocational challenges and those with lower or ill-defined career and personal goals (Stoessel, Ihme, Barbarino, Fisseler, \& Stürmer, 2015).

In an influential article John Daniel, postulated that distance education designs are constrained by three broad constructs - cost, time (to produce) and quality. It has been paraphrased as "good, fast or cheap - pick two". (van Wyngaard, Pretorius, \& Pretorius, 2012, p. 1992) Whichever two you pick, the third inevitably suffers. This model has 
withstood over 45 years of project management research and over 110,000 references in the education literature. Many distance education courses that do fail, or have very low completion rates, do so because of a marked deficiency in at least one of Daniel's constructs.

\section{Student-content interaction}

As noted earlier student-content interaction has always been a key component of distance education systems. Technology has drastically reduced the costs of storing and distributing this content- as for example the amount of content (in multiple formats) that can be stored and distributed globally via first CD and more recently via cloud networks. This has led to the capacity to deploy content at near zero costs as evidenced by the proliferation of MOOCs from 2012 onward. The time to produce content has also decreased given a proliferation of production tools for text, video and audio content (Bates, 2019).

However, education is not just content dissemination - if so, we would all be highly competent PhD scholars merely from watching television. As cost and time for content production has gone down, the quality of their deployment in education has also gone down as evidenced by the very low completion rates of nearly all forms of MOOCs (Reich \& Ruipérez-Valiente, 2019). The issue of cost is multi-sided and complex as we first need to determine if we are talking about institutional cost to produce and deliver or the student cost to access the course, its content and any associated support services. Further, we note the time and opportunity costs to students, teachers and institutions that determine actual cost in any context. Study of the MOOC literature illustrates this as we see the considerable upfront capital cost and regular maintenance of the MOOC as a significant cost variable. On the revenue side, tuition free MOOCs are changing from free to audit but with cost for examination and certification. Recently we see MOOC companies attempting to sell their online content for use on campus and at a distance in a commercial model not unlike text book production (Shi, Li, Haller, \& Campbell, 2018).

Since Dave Cormier coined the term and the first MOOCs were offered in Canada in 2008, MOOCs have moved from a disruptive factor that evangelists claimed would destroy universities to a lower cost, provision of education content designed for continuing professionals and as curriculum for traditional on-campus students. The march from disruption to sustaining (but pitched at different audiences) demonstrates the pervasiveness of the "Iron Triangle": MOOCs are fast, and they are cheap to produce as measured on a per student cost, but the quality (at least as measured by completion rates) is usually low.

\section{Threaded discussion in distance education}

Threaded conferences (forums) were the basis for teaching and learning when distance education evolved from dissemination focus (via print, television or radio) to interactive models of teaching and learning. This initial interaction was in text form, allowing for asynchronous participation and the ability to participate outside of the social pressure of the classroom. Thus, early proponents (Garrison, 1997) of threaded discussion based distance education saw this tool as providing a pathway to constructivist styled class discussion. Moreover, the textual nature of the interaction provided a means for educational researchers to examine both interaction and perhaps even the learning process itself.

Sadly, much of this promise has not been fulfilled. Too often students are forced to use the tool in prescribed ways that do little to reflect and develop their own unique understanding or creation of new knowledge (Morris \& Stommel, 2018). Often students are told how many discussions posts they must originate and respond to, what length they are to be, what day they must be entered, the type of speech act to use, and the prescribed length of their posts. The teacher also often provides a rubric by which the students contributions to the 
discussion is assessed and as noted earlier, learning analytics tools quantitatively measure the value of the students' contributions.

The conferencing technology employed in most learning management systems often supports only text interaction, often prohibits insertion or even direct linking of resources and lacks many of the "likes", export capacity and spontaneity that defines quality learning. As Morris \& Stommel (2018) argue "discussion forums, do not encourage, or in some cases do not allow, students to meet, greet, challenge, question, and collaborate in the dynamic ways they do elsewhere in the web" (online).

In a 2007 review of research purporting to measure the deep and critical thinking of online discussions claimed by early pundits, Maurino (2007) found that "for the most part, however, research does not show this (deep learning and critical thinking) happening at a high level or to any great extent" (p. 241).

Threaded discussion like any educational technology can be used effectively to support high quality learning. However, rarely has the tool evolved to support multimedia posts, social networking, or scaffolding for a variety of educational activities such as debates, presentations, collaborative postings etc. Finally, we see pressure for teachers to expand the number of students in their online classrooms, far beyond the optimal number of 16 students identified by Orellana (2006).

Thus, the ubiquitous threaded discussion, though is the most commonly used tool for online distance education interaction, often fails to provide the high quality, student centered learning that was promised. Like most other distance educational technology tools (analytics, social media and threaded discussions), create pathways and opportunity for formal learning and accreditation to meet a global demand. But this pathway is often driven to meeting the needs of technology providers themselves and the educational administrators striving to reduce cost and improve efficiency - too often at the cost of high-quality learning.

\section{Copyright confusion}

Modern communications technologies support many types of communication, teaching and learning. In addition, "educators, administrators, and students shape technological ecologies for their classrooms, programs, and institutions whenever they make formal and informal choices about which tools to take up, which to eschew, and which to utilize in creative or unexpected ways." (Amidon, Hutchinson, Herrington, \& Reyman, 2019, online). In the process of participating in educational courses, students compose, and create copyright content both individually and through collaborative activities with others. This includes the obvious visible products of their work (essays, graphs, art work etc.) but also the digital record creates and maintains metadata streams that may or (as often as not) reveal and may infringe on the copyright of its creator the students.

As Estee Beck (2015) notes, our interactions in digital educational spaces creates traceable (though invisible to most users) content that exists in a legal grey zone and is little understood and controlled, by its creators and owners: students, teachers, institutions and the IT platform owners. Can these traces be used for recruitment or selection of students for different tasks? Can this be sold to commercial companies?

Given the dependence of most forms of distance on mediated content, it comes as no surprise that educators, publishers and authors have contested the rights of students to consume content and publishers to charge ever increasing amounts for access to that content (Hobbs, 2020). Most copyright laws allow for limited 'fair use' of copyright material for education. However, publishers are quick to assert that this use by educators does not 
extend to full use of their copyright materials in packages sent to students. They argue that educational exemptions from copyright should extend only to infrequent use of an image or quotation in the fleeting moment of a campus classroom. Thus, there has been considerable legal challenges to copyright enforcement - some of which focus directly on use in distance education (Atanasova, 2019).

\section{Utopian, compulsive and excessively optimistic visions}

Attempts to pitch educational technology (by both commercial companies and early adopters) as a universal solution to the problems of education, have largely been unsuccessful (Sancho-Gil, Rivera-Vargas \& Miño-Puigcercós, 2020). A recent example was the promotional hype surrounding virtual environments (such as Second Life) and the rush by many universities to develop virtual campus spaces on these environments. Today most of these campuses are ghost towns and many have been swept away by the march of funding to new schemes. Rather educators are discovering the veracity of Zuboff's (2019)'s claim that "Digital connection is now a means to others' commercial ends. At its core, surveillance capitalism is parasitic and self-referential" (online).

Likely the greatest challenge both for educational technology vendors and for early adopting teachers is the challenge of adoption (at scale) of any new technology. Pundits including Christiansen, Horn \& Johnson (2008) (disruptive technology), Prensky (2001) (digital natives), Siemens (2008) (connectivism) often rely on models and formulas with little empirical support or rigorous theoretical rationale. For example, Prensky continues on the Edtech keynote circuit' idealizing the self-learning and motivation of digital natives, despite the lack of evidence or theory supporting the idea that natives are fundamentally different from digital immigrants (Helsper \& Eynon, 2010; Bayne \& Ross, 2011). More recently educators have been urged to up their level of technology use by using the SAMR model to move from Substitution to Augmentation to Modification until they reach the utopic end state where technology Redefines educational outcomes. In a scathing review of the SAMR model, Hamilton, Rosenberg \& Akcaogla (2016) note that the model discounts the critical effect of context on effective use, lack of evidence for the hierarchical nature of the model and the way the model values the product (use of the technology) over process (what is actually learned).

At the root of the problem of technology utopia is a belief that the tool (or the content) will succeed in any context with any learner - thus, appealing to the opportunity for scaling of distance education provision. This reflects the focus on content that still defines distance education today. As Minnium (2019, online) notes "content may be king, but context is queen". Distance education has traditionally ignored context, seeking a reified form of knowledge that fits in multiple, indeed every context. From both constructivist and connectivist theorists, we know this assumption is false.

Utopian views and exuberant claims of educational technology vendors and pundits need to be confronted and challenged by data from actual use. Given the distributed nature of the distance education context, students and teachers are often invisible to researchers. Nonetheless as notes Selwyn (2010) "greater attention now needs to be paid to how digital technologies are actually being used- for better and worse - in 'real-world' educational settings." (2010, p. 66).

\section{b. Current and future challenges (and risks) of distance education}


Along the same lines as what we have done in the previous dimension, from the review and analysis of the literature, we have identified three important challenges about the future of distance education. Of course, these three elements do not rule out the existence of other challenges. The selection has been made based on the coincidences found in the reviewed texts, and the interests and experience of the authors of this article. Finally, as in the previous dimension, these are presented only with the intention of contributing to the debate and academic discussion about the future of distance education.

\section{The promise and peril of learning analytics in distance education}

Most educational institutions offering distance education in developed countries, do so by using sophisticated and usually cloud based learning management, support and interaction tools. These tools offer a unique advantage to distance education in that the separation of teacher and student often leads to lack of awareness, empathy and understanding of both student learning progress and teacher expectation and assistance.

In face to face classroom contexts students have the benefit of teacher immediacy, and teachers get visual feedback from expressions, questions and attention levels of students they can observe (Frymier, Goldman, \& Claus, 2019). All of this is missing from distance education. Thus, the promise of learning analytics, to provide a means for teachers to observe and interact in learning sequences of students is persuasive. It is assumed that increased level of teacher-student awareness will lead to improved educational outcomes (though to date there is little evidence of this). One of the most visible components of a learning analytic system is a dashboard (either student or teaching facing) that provides visual representations of student progress (in real time) during the course. It is assumed that student's being able to gauge their performance against that of their peers will be motivational and result in higher learning achievement. However, Jivet et al. (2017) found from a review of the dashboard literature that "current designs foster competition between learners rather than knowledge mastery, offering misguided frames of reference for comparison" (p. 82). These findings suggest that learning analytics systems lack strong theoretical justification for their design and use and further we see that analytic based decision making is often based on data most easily collected (time on task, progress through content, etc.) rather than on more robust indicators of knowledge development or application.

Improved learning outcome is one goal, however Long \& Siemens (2011) describe some potential benefits of learning analytics, including:

- better institutional decision making and resource use;

- improved learning for at-risk students;

- increased institutional transparency;

- transformative change to teaching methods;

- better insight into networked knowledge;

- data-driven experimentation for administrative problems (e.g., enrollment and retainment);

- increased "organizational productivity and effectiveness";

- value-ranking of faculty activity;

- comparative learning metrics for students (e.g., how a student compares to her peers in a particular area). 
To accomplish these lofty goals learning analytics systems monitor student and teacher behavior and use a variety of social network analysis, data visualization, clustering, prediction and correlation tools as independent variables in search for evidence from dependent improvements mentioned above.

It is early days, but existing learning analytics research often lacks strong theoretical basis. To Bodily \& Verbert (2017) "experiments to determine the effect of these systems on student behavior, achievement, and skills are needed to add to the small existing body of evidence" (p.2). Many studies do find improvement in learning outcomes (especially those associated with knowledge acquisition) and in learning support after addition of learning analytics based interventions, however even more studies defend the researchers' belief in the potential for learning analytics ${ }^{5}$. A continuing challenge to educational technology research is that most of the prolific researchers are also the most enthusiastic evangelists for the technology. Too often 'research' in distance education contexts consists of less than robust evidence from early adopters.

But what of the risks associated with learning analytics? Any technology with the potential to change and challenge established teacher and student behavior is bound to come with risks. Both students and teachers ask, "what's in it for me" and what are the risks (Howell, Roberts, Seaman \& Gibson, 2018). Assessing risks depends on a number of variables, but perhaps most importantly are those associated with the ownership of the data. Many learning analytics solutions use commercial and cloud based services. As we will see in the section on social media use, it is impossible to verify how, when and to what extent this data will be used by others either authorized or unauthorized by students, teachers or institutions.

In an insightful essay on the growing use of learning analytics in higher education Rubel \& Jones (2016) challenge institutions to answer 5 questions before embarking on the analytics journey.

1. who all may access student information and for what purposes?

2. Is it, though useful, too intrusive to warrant collection and analysis?

3. Is there continuing evidence that the collection of data is actually useful and results in improved learning?

4. Does learning analytic benefits justify the cost and potential for breach of privacy that inevitably accompanies learning analytics?

5. Are the benefits of learning analytics integrated and supportive of the overall goals of education including autonomy, respect for differences, social justice, student health and well-being?

There are very few if any distance education institutions currently exploring learning analytics that adequately address these questions.

Virginia Eubanks (2009) provides compelling evidence that automating welfare services creates a big brother type of "digital poor house" that disproportionately monitors and distrusts its clients. This is one reason that some schools refuse to engage in learning analytics or that encourage official use of external social networking systems for fear that the data will be misused by an external profit or politically motivated firm. Work on the "hidden curriculum" of higher education (Ahola, 2000; Margolis \& Romero, 1998) reveals the class, caste, race and religious basis for access to and success at higher education. Distance education, with its primary mission of increasing access, prides itself on spanning these

\footnotetext{
${ }^{5}$ To achieve these lofty goals, see for example Bodily \& Verbert (2017).
} 
barriers, but digital poorhouses warn of ways in which data (from students and teachers, rich and poor) can be both usefully used and woefully abused.

Increasingly, in their pedagogic and administrative management, both campus and distance institutions are taking advantage of software programs, platforms and services that are provided free or very low cost by private companies (or their associated foundations). In exchange for free access to the tools and platform, the company gains access to the data stream thus making moving educational interactions into private and proprietary context. For Regan \& Steeves (2019) this results in educational generated information flow being "collected and used by the companies to further a particular view of education, not one accepted as the public or common good, and the data remain in the hands of the private companies." (2019: online).

\section{Social media in distance education}

Given that distance education often suffers from social isolation or what Moore (1993) refers to as "transactional distance", tools that are designed to increase socialization may be both effective and welcomed by both students and teachers. "What characterizes social media applications as learning environments are their accentuated interactivity and, as the label suggests, their socialness: these platforms permit to pave the way for active, constructivist pedagogies" (Bolanos \& Ketola, 2018: online). However, these tools (owned and operated by proprietary companies) also have become associated with privacy invasion, manipulation of users and total lack of transparency.

Many published studies (often by early adopters) have claimed that use of social media has been well received by students - especially in systems that rely on first generation printed content ${ }^{6}$. However, a review of the literature by Zayer et al. (2017), reports that students face three types of challenges using social media within formal education courses.

Firstly, the challenge of maintaining personal boundaries and limits. Do students really want to be-friend other students and even more so the teacher? What does friendship mean in these contexts?

Secondly, Zayer et. al. (2017) note that students have difficulty establishing legitimacy. In an era of false news and suspect scholarship (predatory journals) this is not surprising, but it is perhaps useful exposure and challenge to students.

Thirdly, they note the challenge of managing relevance. How many of us can claim they have never wasted hours pursuing topics on social media that may have started out as educational, but end up in a nonproductive waste of time?

Given both the speed of introduction (and in some cases limited half-life) of social media coupled with inherent resistance to change of many educational institutions, it is perhaps not surprising that adoption has been a major challenge for both advocates and resistors of educational technology.

A common concern with faculty is the ever-growing expansion of their disciplinary knowledge and thus a sense that they must teach everything. Such thinking is grounded in behavioural and cognitive learning theory that stresses need for authoritative and well-structured information transmission. Social media hardly excels using these criteria. In an interesting study of medical teachers Flynn, Jalali, \& Moreau (2015) note that only constructivism and connectivism provide the rationale and point to effective learning activities that match the affordances of social media. Unfortunately, connectivism remains a challenging theory to

\footnotetext{
6 See for example: Madge et al., (2019) and Heller (2019).
} 
implement with the strictest outcome based curriculum (Kop \& Hill, 2008; Wade, 2012). Finally, constructivism develops and is most much easier to implement with the high degree of immediateness both inside and outside of campus classrooms. These polar opposite views related to the desirability of adding ever more sophisticated and interactive technology to distance education programming, has resulted in deep frustrations among both advocates and conservative educators (Lee, 2019)

As noted, many of the concerns related to social media in education use relate the commercialization and inherent proprietary secrecy of commercial companies which own these services. To address this challenge a number of researchers have explored social media use on closed platforms (ie elgg or Ning) that are owned and managed by educational institution itself. Quong, Snider, \& Early (2018) concluded "The results provide evidence to support the use of closed social networks as tools to enhance students' engagement, interaction, and social presence as well as to reduce transactional distance in online and blended learning environments. The efforts in the Athabasca University (Dron \& Anderson, 2014) show similar promise however adoption by faculty and administration remains challenging.

\section{Assimilation or singularity}

Many, and in some countries nearly all, campus-based universities now offer online courses. Calvert (2005) noted "Institutions see distance education as a means of enrolling more students, broadening their student base, generating fee revenue, offering courses in niche markets and meeting their regional commitments cost effectively" (p. 229). With the rise of more flexible and cost-effective means of development and delivery, has come awareness of the vulnerability of those institutions that are "single-mode" and that only offer distance and online courses (Rumble, 1992). In addition, most of the open and distance education universities globally suffer from lower prestige, lower research accomplishments and reduced per-student government funding than their campus counterparts (Puspitasari \& Djaya, 2009). Thus, as long ago as 1992, Rumble (1992) was suggesting the imminent demise of single-mode distance education universities.

A second issue confronting the open and distance education institutions is associated with the challenges to academics of working in a teaching and learning environment that for most is different from both their experience as students and their expectations as faculty. Lee (2019) in a qualitative research with either distance educators put in evidence that the open universities suffer from "excessive openness and a lost sense of mission; irrational technological innovation; moving online and long-lasting resistance; challenging transactional interactions; and feelings of loneliness" (p. 21).

However, there is a growing body of evidence showing that, despite the competition, many of these distance education institutions continue to survive and especially in the global south to thrive. Many of these institutions have had challenges relating not only to new competition, but also to challenges associated with shifting technologies and pedagogies and changes in student demographics. In response, distance education increasingly is focusing on post- graduate students and provision of diplomas and certificates targeted at working professionals and its traditional market of those who have difficulty meeting financial and academic requirements of campus based universities. Many of these students need and value the flexibility and the time and place shifting afforded by online and distance education. As noted this flexibility is increasingly offered by more prestigious campus based universities, however campus based institutions also have trouble in attracting willing faculty teachers and insuring student and faculty support systems both on campus and at a distance (Jacobs, 2013) 
As Paul \& Tait (2019) illustrate in Figure 1. The open universities face significant weaknesses, threats and opportunities in addition to strengths.

\begin{tabular}{|c|c|}
\hline $\begin{array}{l}\text { Strengths } \\
\text { - Commitment to openness, flexibility, and } \\
\text { access. } \\
\text { - Capacity for large-scale provision. } \\
\text { - Support for part-time students, working } \\
\text { adults. } \\
\text { - Commitment to technology-enhanced } \\
\text { learning. }\end{array}$ & $\begin{array}{l}\text { Opportunities } \\
\text { - World-wide access to the Internet. } \\
\text { - UN's sustainable development goals for } \\
\text { major expansion of higher education. } \\
\text { - Use experience to develop quality } \\
\text { assurance for mass higher education } \\
\text { systems. } \\
\text { - Trends to international collaboration, } \\
\text { open educational resources. } \\
\text { International trends to lifelong learning } \\
\text { and continuous professional upgrading. }\end{array}$ \\
\hline $\begin{array}{l}\text { Weaknesses } \\
\qquad \text { - Completion and graduation rates. } \\
\text { - Reputation and brand. } \\
\text { - Staff resistance to change. } \\
\text { - OU model based on very large student-to- } \\
\text { staff ratio. }\end{array}$ & \begin{tabular}{l}
\multicolumn{1}{c}{ Threats } \\
- Burgeoning mainstream university \\
involvement in online and blended \\
learning. \\
- Governmental disenchantment with OU \\
model. \\
- Supreme value of elite education. \\
- MOOCs and other innovations from \\
mainstream universities.
\end{tabular} \\
\hline
\end{tabular}

Figure 1. SWOT analysis for Open Universities

Source: From Paul \& Tait (2019) p. (iii)

While we have limited capacity to look into the future, it seems that the predictions of the imminent death of single-mode open and distance education institutions have been exaggerated. However, there is also little doubt that they face an uncertain future. This uncertainty of future effects both students' willingness to enroll and faculty willingness to accept employment. However, for all types of higher education are dealing with demands for increased effectiveness and reduced government funding. The open institutions have in the past been more cost effective and offered lower tuition than the campus based institutions (Olakulehin \& Panda, 2011), but there are no guarantees that these advantages will continue into an increasingly competitive higher education context.

\section{Conclusion}

A surface understanding of the trends described in this work, could lead the reader to think that the main challenge that distance education institutions have today is related to investing, developing and incorporating more digital technologies in the teaching dynamics and institutional management. However, this reflection seeks to propose a different perspective. In this way, we return to our initial questions: (1) What aspects have not been 
completely satisfactory in the transit and transformation that Distance Education has undergone, in its most traditional conception, towards its new configuration marked by the active use of digital technologies and environments? (2) In order to ensure the sustainability of this teaching model, what are the future challenges that distance education will face?

In relation to the first question, from the traditional definition of Distance Education, until the current digital version, we have proposed five outstanding shortcomings:

Attrition rates. Distance education presents high attrition rates, especially in those distance education systems that provide low levels of student support and those that use less interactive media and instructional teaching and learning designs.

Student-content interaction. Technology has reduced the costs of storing and distributing content. However, the quality of their deployment in education has also gone down as evidenced by the very low completion rates of nearly all forms of MOOCs.

Threaded discussion in distance education. One of the main problems of this tool, is that usually students are forced to use this tool in prescribed ways that do little to reflect and develop their own unique understanding or creation of new knowledge.

Copyright confusion. In the process of participating in educational courses students compose, and create copyright content both individually and through collaborative activities. This includes the obvious visible products of their work (essays, graphs, art work etc.) but also the digital record creates and maintains metadata streams that may reveal and infringe on the copyright of its creator.

Utopian, compulsive and excessively optimistic visions. Attempts to pitch educational technology as a universal solution to the problems of education, have largely been unsuccessful, including distance education.

In relation to the second question, we have proposed three important challenges that distance education must face.

The promise and peril of learning analytics in distance education. As we have seen, assessing risks depends on a number of variables, perhaps most importantly are those associated with the ownership of the data. Many learning analytics solutions use commercial and cloud based services and it is impossible to verify how, when and to what extent this data will be used by others either authorized or unauthorized by students, teachers or institutions.

Social media in distance education. In distance education, tools that are designed to increase socialization may be both effective and welcomed by students and teachers. However, these tools (owned and operated by proprietary companies) also have become associated with privacy invasion, manipulation of users and total lack of transparency.

Assimilation or singularity: At present, more and more universities on campus offer an online training, which has been an important challenge for distance universities in order to maintain their uniqueness and appeal. In any case, this phenomenon together with others of manifest relevance (tuition cost, blended attendance, possibility of generating networking ...) do nothing but evidence the legitimacy challenge that higher education institutions must face as a whole.

As we mentioned, these proposed elements (shortcomings and future challenges) do not represent taxative responses, much less rule out the existence of other critical elements. The selection has been made based on the similarities found in the revised texts, and the interests and experience of the authors of this article. Finally, they are presented only with 
the intention of contributing to the academic discussion about the past and present of distance education.

As a final reflection, the pro-knowledge society rhetoric, labeled 4.0 (Mazali, 2018) placed universities at the center of the debate and assigned them a privileged position. Universities will likely play a key role in the digital era to produce relevant knowledge and train new generations of workers. However, the multiple inertias that have been orienting the financial market to an important part of the production that universities offer, have enabled economic sectors to take advantage of this position of relevance (Rivera-Vargas \& Cobo, 2019). In this way, to be able to reduce as much as possible the ethos of the university under a rationale of commercialization, characterized by: excessive growth in enrolment; productivity rankings; compulsory practices of dissemination of scientific knowledge; accumulation practices of the best: students, teachers, facilities, etc.

These challenges effect both campus and distance education universities, however the intense mediation associated with online and distance education makes them especially vulnerable. Increasingly high expectations from students for high quality (and expensive) media as well as challenges in expanding markets beyond national boundaries and gaining the necessary economy of scale further constrains distance education institutions. Finally, like all modern organizations, confronting the challenges of "online life" is both risky and expensive. Issues of online privacy, copyrighting and increasing digital and campus competition abound. Distance education institutions cannot rest on decades of tradition and elite support that has defined their campus based competitors. Thus, they and their students face a perilous future.

\section{References}

Ahola, S. (2000). Hidden curriculum in higher education: Something to fear for or comply to? Presented at the Innovations in Higher Education.

Alfonso, I. (2003). La educación a distancia. Revista cubana de los profesionales de la información y la comunicación en salud. 11(1), 1-13

Amidon, T. R., Hutchinson, L., Herrington, T. K., \& Reyman, J. (2019). Copyright, Content, \& Control: Student Authorship across Educational Technology Platforms. 24.1. Retrieved from http://kairos.technorhetoric.net/24.1/topoi/amidon-et-al/index.html

Anderson, T. (1999). Using disruptive technologies in the Universities: Confessions of an Agent Provocateur. Presented at the Ed-Media World Conference on Educational Multimedia, Hypermedia and Telecommunications, 1999, Seattle: AACE

Anderson, T. (2003). Modes of interaction in distance education: Recent developments and research questions. In M. Moore \& W. Anderson (Eds.), Handbook of Distance Education (pp. 129-144). Mahwah, NJ: Erlbaum.

Anderson, T., \& Dron, J. (2012). Learning technology through three generations of technology enhanced distance education pedagogy. European Journal of Open, Distance and E-Learning, 2, 1-14. Retrieved from: https://files.eric.ed.gov/fulltext/EJ992485.pdf

Atanasova, I. (2019). Copyright Infringement In Digital Environment. Economics \& Law, 1(1), $13-22$.

Bates, A. W. (2005). Technology, E-learning and Distance Education. New York: Routledge.

Bates, A. W. (2019) Teaching in a digital age. 2nd Ed. Campus BC. https://opentextbc.ca/teachinginadigitalage/.

Bayne, S., \& Ross, J. (2011). 'Digital Native' and 'Digital Immigrant' Discourses: A Critique. Digital Difference, 159-169. https://doi.org/10.1007/9789460915802_013

Beck, E. N. (2015). The Invisible Digital Identity: Assemblages in Digital Networks. Computers and Composition, 35, 125-140. https://doi.org/10.1016/j.compcom.2015.01.005

Bodily, R., \& Verbert, K. (2017). Review of research on student-facing learning analytics dashboards and educational recommender systems. IEEE Transactions on Learning Technologies, 10(4), 405418 
Bolanos, A., \& Ketola, A. (2018). Social media platforms in translator training: Socialising or separating? Trans-Kom, 11, 183-200.

Calvert, J. (2005) Distance Education at the Crossroads, Distance Education, 26(2), 227-238, DOI: $10.1080 / 01587910500168876$

Castañeda, L., y Adell, J. (2013). Entornos Personales de Aprendizaje: claves para el ecosistema educativo en red. Alcoy: Marfil

Christensen, C., Horn, M., \& Johnson, C. (2008). Disrupting Class: How Disruptive Innovation Will Change the Way the World Learns. New York: McGraw Hill.

Daniel, J. (2013). Mega-universities and knowledge media. Routledge.

Deiman, M. \& Farrow, R. (2013). Rethinking OER and their use: Open education as Bildung. The International Review of Research in Open and Distributed Learning, 14(3). https://doi.org/10.19173/irrodl.v14i3.1370

Dolan, V. L. (2014). Massive online obsessive compulsion: What are they saying out there about the latest phenomenon in higher education? The International Review of Research in Open and Distributed Learning, 15(2), 268-281. doi: https://doi.org/10.19173/irrodl.v15i2.1553

Dron, J., \& Anderson, T. (2014). Teaching crowds: Learning and social media. Athabasca University Press.

Eubanks, V. (2009). Double-Bound: Putting the Power Back into Participatory Research. Frontiers: $A$ Journal of Women Studies, 30(1), 107-137.

Fallon, C., \& Brown, S. (2016). E-learning standards: a guide to purchasing, developing, and deploying standards-conformant e-Learning. Florida, USA: CRC Press.

Frymier, A. B., Goldman, Z. W., \& Claus, C. J. (2019). Why nonverbal immediacy matters: A motivation explanation. Communication Quarterly, 67(5), 526-539.

Flynn, L., Jalali, A., \& Moreau, K. A. (2015). Learning theory and its application to the use of social media in medical education. Postgraduate Medical Journal, 91(1080), 556. https://doi.org/10.1136/postgradmedj-2015-133358

Gaebel, M., Kupriyanova, V., Morais, R., \& Colucci, E. (2014). E-learning in European higher education institutions: results of a mapping survey conducted in October-December 2013. Brussels: European University Association Press. Retrieved from: http://www.eunis.org/wpcontent/uploads/2015/02/e-Learning-survey2.pdf

Garrison, D. R. (1985). Three generations of technological innovations in distance education. Distance Education, 6(2), 235-241.

Garrison, D. R. (1997). Computer conferencing: The post-industrial age of distance education. Open Learning, 12(2), 3-11.

Garrison, D. R. \& Anderson, T. (2005). El e-Learning en el siglo XXI: Investigación y práctica. Barcelona: Octaedro.

Gossenheimer, A. N., Bem, T., Carneiro, M. L. F., \& de Castro, M. S. (2017). Impact of distance education on academic performance in a pharmaceutical care course. PloS One, 12(4), e0175117.

Guri-Rosenblit, S. \& Gros, B. (2011). e-Learning: confusing terminology, research gaps and inherent challenges. Journal of Distance Education, 25(1), 1-17.

Hamilton, E. R., Rosenberg, J. M., \& Akcaoglu, M. (2016). The Substitution Augmentation Modification Redefinition (SAMR) Model: A Critical Review and Suggestions for its Use. TechTrends, 60(5), 433-441. https://doi.org/10.1007/s11528-016-0091-y

Harasim, L. (2000). Shift happens: Online education as a new paradigm in learning. The Internet and higher education, 3(1-2), 41-61.

Heller, L. (2019, March 18). Social Media Closing the Distance in Online Education. 81-91. Retrieved from https://www.learntechlib.org/primary/p/208491/

Helsper, E. J., \& Eynon, R. (2010). Digital natives: where is the evidence? British educational research journal, 36(3), 503-520. https://doi.org/10.1080/01411920902989227

Hobbs, R. (2020). Copyright and Fair Use. In The International Encyclopedia of Media Literacy (eds R. Hobbs and P. Mihailidis). doi:10.1002/9781118978238.ieml0039

Howell, J. A., Roberts, L. D., Seaman, K., \& Gibson, D. C. (2018). Are We on Our Way to Becoming a "Helicopter University"? Academics' Views on Learning Analytics. Technology, Knowledge and Learning, 23(1), 1-20. https://doi.org/10.1007/s10758-017-9329-9

Huang, E. Y., Lin, S. W., \& Huang, T. K. (2012). What type of learning style leads to online participation in the mixed-mode e-Learning environment? A study of software usage instruction. Computers \& Education, 58(1), 338-349. https://doi.org/10.1016/j.compedu.2011.08.003 
Jacobs, P. (2013). "The challenges of online courses for the instructor." Research In Higher Education 21(2013): 1-18

Jivet, I., Scheffel, M., Drachsler, H., \& Specht, M. (2017). Awareness Is Not Enough: Pitfalls of Learning Analytics Dashboards in the Educational Practice. In É. Lavoué, H. Drachsler, K. Verbert, J. Broisin, \& M. Pérez-Sanagustín (Eds.), Data Driven Approaches in Digital Education (pp. 8296). London: Springer International Publishing.

Kaplan, A. M., \& Haenlein, M. (2016). Higher education and the digital revolution: About MOOCs, SPOCs, social media, and the Cookie Monster. Business Horizons, 59(4), 441-450. doi: https://doi.org/10.1016/j.bushor.2016.03.008

Keegan, D. (1993). Theoretical Principles of Distance Education. NY: Routledge.

Kirkwood, A. (2014). Teaching and learning with technology in higher education: Blended and distance education needs 'joined-up thinking' rather than technological determinism. Open Learning: The Journal of Open, Distance and e-Learning, 29(3), 206-221. https://doi.org/10.1080/02680513.2015.1009884

Kocdar, S., Karadeniz, A., Bozkurt, A., \& Buyuk, K. (2018). Measuring Self-Regulation in Self-Paced Open and Distance Learning Environments. The International Review of Research in Open and Distributed Learning, 19(1). 25-43. https://doi.org/10.19173/irrodl.v19i1.3255

Kop, R., \& Hill, A. (2008). Connectivism: Learning theory of the future or vestige of the past? The International Review of Research in Open and Distance Learning, 9(3).

Lee, K. (2019). Rewriting a History of Open Universities: The International Review of Research in Open and Distributed Learning, 20(4), 21-35. https://doi.org/10.19173/irrodl.v20i3.4070

Long, P. \& Siemens, G. (2011). Penetrating the fog: Analytics in learning and education. EDUCAUSE Review, 46(5), 30-32.

Madge, C., Breines, M. R., Dalu, M. T. B., Gunter, A., Mittelmeier, J., Prinsloo, P., \& Raghuram, P. (2019). WhatsApp use among African international distance education (IDE) students: Transferring, translating and transforming educational experiences. Learning, Media and Technology, 44(3), 267-282. https://doi.org/10.1080/17439884.2019.1628048

Margolis, E., \& Romero, M. (1998). The department is very male, very white, very old, and very conservative: The functioning of the hidden curriculum in graduate sociology departments. Harvard Educational Review, 68(1), 1-32.

Maurino, P. S. M. (2007). Looking for Critical Thinking in Online Threaded Discussions. Journal of Educational Technology Systems, 35(3), 241-260. https://doi.org/10.2190/P4W3-8117-K32GR34M

Mazali, T. (2018). From industry 4.0 to society 4.0, there and back. AI y SOCIETY, 33(3), 405-411.

Minnium, P. (2019, March 19). Content may be king, but context is queen. Marketing Land. Retrieved from https://marketingland.com/content-may-be-king-but-context-is-queen-258586

Moore, M. (1993). Theory of transactional distance. In D. Keegan (Ed.), Theoretical Principles of Distance Education (pp. 22-38). Routledge.

Morris, S. M., \& Stommel, J. (2018). The Discussion Forum is Dead; Long Live the Discussion Forum. In an Urgency of Teachers. Retrieved https://criticaldigitalpedagogy.pressbooks.com/chapter/the-discussion-forum-is-dead-long-livethe-discussion-forum/

Noble, D. (1998). Digital diploma mills: The automation of higher education. First Monday, 3(1-5).

Olakulehin, F. K., \& Panda, S. K. (2011). Private Cost of Education: A Comparative Study of Distance and Campus-Based University Students in Nigeria. European Journal of Open, Distance and Elearning.

Oregon, E., McCoy, L., \& Carmon-Johnson, L. (2018). Case Analysis: Exploring the Application of Using Rich Media Technologies and Social Presence to Decrease Attrition in an Online Graduate Program. Journal of Educators Online, 15(2), 1-13.

Orellana, A. (2006). Class Size and Interaction in Online Courses. Quarterly Review of Distance Education, 7(3), 229-248.

Paul, R. \& Tait, A. (2019). Special Issue: Open Universities: Past, Present and Future. International Review of Research in Open and Distributed Learning, 20 (4), i-viii. https://doi.org/10.19173/irrodl.v20i4.4575

Prensky, M. (2001). Digital natives, digital immigrants. On the Horizon, 9(5), 1-6.

Puspitasari, S., \& Djaya, A. (2009). Preparing Universitas Terbuka For a World-Class University Through International Ranking System. Asian Association of Open Universities Journal. http://simpen.Ippm.ut.ac.id/htmpublikasi/diki.pdf 
Quong, J., Snider, S. L., \& Early, J. (2018). Reducing Transactional Distance in Online and Blended Courses Through the Use of a Closed Social Media Platform. Journal of Educational Technology Systems, 47(1), 79-100. https://doi.org/10.1177/0047239518766654

Regan, P. M., \& Steeves, V. (2019). Education, privacy, and big data algorithms: Taking the persons out of personalized learning. First Monday, 24(11). https://doi.org/10.5210/fm.v24i11.10094

Reich, J., \& Ruipérez-Valiente, J. A. (2019). The MOOC pivot. Science, 363(6423), 130-131.

Rivera-Vargas, P., \& Cobo Romaní, C. (2019). La universidad en la sociedad digital: entre la herencia analógica y la socialización del conocimiento. REDU. Revista de Docencia Universitaria, 17(1), 17-32.

Rivera-Vargas, P., Alonso, C., y Sancho, J.M. (2017). Desde la educación a distancia al e-Learning: emergencia, evolución y consolidación. Revista educación y tecnología, (10), 1-13.

Rivera-Vargas, P., Sancho-Gil, J. M., y Sánchez, J. A. (2017). Los límites de la disrupción en el orden académico. La cultura DIY en la universidad. Páginas de Educación, 10(2), 127-142. doi: https://doi.org/10.22235/pe.v10i2.1428

Rubel, A., \& Jones, K. M. (2016). Student privacy in learning analytics: An information ethics perspective. The Information Society, 32(2), 143-159.

Rumble, G. (1992). The competitive vulnerability of distance teaching universities. Open Learning, 7(2), 31-45.

Russell, T. L. (1999). The no significant difference phenomenon: As reported in 355 research reports, summaries and papers. Westwern Cooperative for Educational Technologies.

Sancho-Gil, J. M., Rivera-Vargas, P., \& Miño-Puigcercós, R. (2020). Moving beyond the predictable failure of Ed-Tech initiatives. Learning, Media and Technology, 45(1), 61-75. https://doi.org/10.1080/17439884.2019.1666873

Sangrà, A., Vlachopoulus, D. \& Cabrera, N. (2011). Building an inclusive definition of e-Learning: An approach to the conceptual framework. The International Review of Research in Open and Distance Learning, 13(2). 145-159. https://doi.org/10.19173/irrodl.v13i2.1161

Seaman, J., Allen, E. \& Seaman, J. (2018). Grade Increase: Tracking Distance Education in the United States. New York: Babyson Survey Group. Retrieved from: https://onlinelearningsurvey.com/reports/gradeincrease.pdf

Sefton-Green, J., \& Erstad, O. (2017). Researching 'learning lives'-a new agenda for learning, media and technology. Learning, Media and Technology, 42(2), 246-250. doi: https://doi.org/10.1080/17439884.2016.1170034

Selwyn, N. (2010). Looking beyond learning: Notes towards the critical study of educational technology. Journal of Computer Assisted Learning, 26(1), 65-73.

Shachar, M. \& Neumann. (2010). Twenty Years of Research on the Academic Performance Differences Between Traditional and Distance Learning: Summative Meta-Analysis and Trend Examination. Journal of Online Learning and Teaching, 6(2), 318-334.

Shi, Y., Li, X., Haller, A., \& Campbell, J. (2018). Knowledge pricing structures on MOOC platform-A use case analysis on edX. Proceedings of the the Twenty-Second Pacific Asia Conference on Information Systems, Japan 2018. Retrieved from: https://bit.ly/2Y2IEqg

Siemens, G. (2008). Learning and knowing in networks: Changing roles for educators and designers. ITFORUM for Discussion, 27, 1-26.

Stoessel, K., Ihme, T. A., Barbarino, M.-L., Fisseler, B., \& Stürmer, S. (2015). Sociodemographic diversity and distance education: Who drops out from academic programs and why? Research in Higher Education, 56(3), 228-246.

Taylor, J. (1995). Distance education technologies: The fourth generation. Australian Journal of Educational Technology, 11(2), 1-7.

van Wyngaard, C., Pretorius, J., \& Pretorius, L. (2012). Theory of the Triple Constraint - A Conceptual Review. Proceedings of the 2012 IEEE International Conference on Industrial Engineering and Engineering Management. Retrieved https://ieeexplore.ieee.org/abstract/document/6838095

Viberg, O., Hatakka, M., Bälter, O., \& Mavroudi, A. (2018). The current landscape of learning analytics in higher education. Computers in Human Behavior, 89, 98-110. https://doi.org/10.1016/j.chb.2018.07.027

Wade, M. C. (2012). A Critique of Connectivism as a Learning Theory. Cybergogue. Retrieved from: http://cybergogue.blogspot.com/2012/05/critique-of-connectivism-as-learning.html 
Wang, Z., Anderson, T., Chen, L., \& Barbera, E. (2017). Interaction pattern analysis in cMOOCs based on the connectivist interaction and engagement framework. British Journal of Educational Technology, 48(2), 686-699. https://doi.org/10.1111/bjet.12433

Zayer, L., Beran, S., \& Purification, A. (2017). Exploring the challenges of social media in higher education. In The Dark Side of Social Media: A Consumer Psychology Perspective. London: Routledge.

Zuboff, S. (2019) Professor Shoshana Zuboff on Surveillance Capitalism Q\&A. FindCTRL. Retrieved from: https://findingctrl.nesta.org.uk/text/shoshana-zuboff

Zuboff, S. (2019). The Age of Surveillance Capitalism: The Fight for a Human Future at the New Frontier of Power. New York: PublicAffairs. 